\title{
Teachers' Perceptions of the Educational Platform-Is There a Connection between School Improvement and Regional Educational Development?
}

\author{
Lena Boström ${ }^{1}$, Rolf Dalin ${ }^{2}$ \\ ${ }^{1}$ Department of Education, Mid Sweden University, Härnösand, Sweden \\ ${ }^{2}$ Department of Information Technology and Media, Mid Sweden University, Sundsvall, Sweden \\ Correspondence: Lena Boström, Department of Education, Mid Sweden University, Universitetsbacken 1, 87188 \\ Härnösand, Sweden
}

Received: October 8, 2015 Accepted: October 19, 2015 Online Published: October 21, 2015

doi:10.11114/jets.v4i2.1114 URL: http://dx.doi.org/10.11114/jets.v4i2.1114

\begin{abstract}
This research examined teachers' attitudes in a school development project, The best regional educational system in the world which focuses on regional development and school improvement. The project was performed in counties in Mid Sweden, which have a lower educational level and school achievements and a competence escape compare with other parts of Sweden. Project schools were compared to references schools concerning staffs perception of the pedagogical platform. This study is based on a web-based survey. The quantitative results show that two of the factors in the survey distinguished themselves with statistical significance; namely, the pedagogical platform was $0.44(\mathrm{p}=0.036)$ and leadership factor, which was $0.25(\mathrm{p}=0.052)$ was lower for the project schools. The directed content analysis showed differences regarding awareness of the pedagogical platform concerning understanding vs. ambiguity and specifically targeting vs. general descriptions. The reference schools described an understanding of the school's overall educational platform and described more clearly the school's focus. The study points to the importance of teachers are aware of their own school platform to develop leadership and teams, which in turn influences student learning and achievement. If schools in the two counties are to be successful, in terms of students' school performance and the competitiveness of the region, the pedagogical platform should be made clear to staff and be anchored in the teachers' team work, probably even more than in other schools.
\end{abstract}

Keywords: regional educational development, school improvement, pedagogical platform

\section{Introduction}

The starting point for this study is a school development project, the best regional educational system in the world (V brus), which focuses on regional development and school improvement in two Swedish counties, Västernorrland and Jämtland. Representatives from private and public sectors in the region and researcher at Mid Sweden University began a three-year research project in autumn 2012 with the aim to develop the region by improving the situation for students, to develop the practical school activities and leadership in school and research improvement and development. Three schools which were selected to be part of the project, was judged to have good opportunities to develop and thus become good role models for other schools, even after the project period. The intention behind the V- brus-project is to enable a region Mid Northland to develop in a positive way for people, businesses and the public sector (Mittuniversitetet, 2012).

The present sub study of the project is about teachers' perceptions of the so-called pedagogical platform in the three project schools and three reference schools. Are the perceptions distinctive and, if so, in what ways? The term"pedagogical platform", stands for the starting points the staff from a holistic perspective (cf. Scherp, 2011). The object of study is thus teachers' perceptions on various aspects of the educational platform where project schools' responses are compared with the reference schools' responses. One hope is that invisible and collective values can be made visible (cf. Fanzén, 2011). In this way, internal school improvement, which could ultimately benefit the regional development, could be described. First there will be a brief presentation of the school development project with relevant background research and then an introduction of the study's methodological approach. Then systematically treated the empirical material in accordance with analysis categories, and finally findings, conclusions and possible implications are presented. 


\subsection{Background}

The background to the project originated in the multi-stakeholder seen that students in the two counties of Jämtland and Västernorrland, especially in mainstream school, performing worse with regard to merit ratings and attainment. The national school results in some parts of the region steadily declined for nine years (Swedish National Agency 2014 a, b). In addition the level of education is lower compared to other parts of the country; far too few of the students at the region's universities come from and / or stay in the region and the relatively large proportion of highly educated moves from the region (Statistiska centralbyrån, 2014).

The underlying assumption is that good education system, from kindergarten to university, is essential for regional development. This reciprocal relationship means that the initiatives in the class room is influenced by the surrounding context of school, region and nation (Hernandez \& Goodson, 2010; Veugelers \& Ziljsra, 2010). This is important not only from a regional perspective, but also from a national and international context. In other words, and regional education can contribute to the regions' welfare (Ambos \& Schlegelmich, 2010; Florida, 2002; Florida, Mellander, \& Stolarick, 2010).

\subsection{School Improvement}

In this article the regional perspective is in the background in favor of school developmentally perspectives and internal areas of improvement. We would, however, say that the theoretical assumptions we describe in the next section also has been the basis of the content.

Research, both nationally and internationally on school improvement seems to be very extensive (Berg \& Scherp, 2009). What is international research pointing on existing schools' internal readiness and capacity to implement improvement processes? More comprehensive, critical parameters emphasized are structure, culture and leadership (Höög, \& Johansson, 2014), which are also separately described by various researchers. Teacher collaboration on school content and curriculum, seems crucial to influence the structure (Höög \& Johansson 2011), but also working in teams and learning communities is emphasized (Björkman, 2008). Three internal improvement capabilities which seem to be particularly important for school improvement process is cooperation, both external and internal, skills development and leadership (Björkman, 2008; Blossing, 2008). Successful schools usually work in teams' hub for development, with a distinct leader. These teams are familiar with the school's aims and objectives. The individual importance of leadership in a larger context to influence school culture are described by several researchers (Fullan, 2010; Bredeson, 2002). Classroom management another dimension described by Ertesvåg (2009), Pounder (2009) and Steinberg (2012), and these researchers point out in particular the importance of the didactic conscious choices teachers make.

Especially important for this study, is that teachers' values and basic assumptions that form different identity groups. Olofsson (2014) shows, that teachers' professional identities coincide with the school's ability to reach both learning and social objectives. Cultures are designed and repercussion on the common work. Thus, the school culture that prevails will be either an obstacle or an aid to teachers' assignments. However, teachers' collective professional identities visible and change eg through stories (Löfgren, 2010). To make visible the invisible act in this study, is to highlight the collective perceptions (cf. Franzen, 2011) in project schools compared to the reference schools. The fact that there may be various pedagogical beliefs in rural schools depending on the prevailing culture and staffing, is described by Dimenäs et al. ( 2013) and relationship and contextual factors in rural schools and small could be advantageous for school improvement (Chance \& Segura, 2009).

\subsection{Regional Development and School Improvement}

The last decade has witnessed a significant expansion and development in the field of regional educational research (From \& Olofsson, 2014). Internationally, there is a broad research from different disciplines on Regional Development (Boström, 2015b). Good education, from kindergarten to university, is crucial for regional development, but the research is moving most of higher education and research are calling from kindergarten through the entire school system (Bostrom, 2015a). Not unimportant in this context is dichotomization of urban and rural values that come with the debate and research on regional development (eg Kauppila, 2011; Klaesson \& Pettersson, 2009; Rönnblom; 2014) and the concept of " urban prevail " occurs frequently in this context.

Surprisingly few international studies are linking regional development and school improvement. Different regions, countries and continents define regional development in different ways and thus problems become also different. Countries and continents have different economic and structural conditions and guidelines. For example, regional school improvement does not mean the same thing in West Africa compared to northern Canada. What seems to be common issues throughout the world, however, the concerns relating to urbanization, rural depopulation / rural areas, the need elucidate factors regional development and a belief in education. Development in this context is usually about higher education, while factors involving main stream schools has not been researched any great extent (Boström, 2015b). 
However, parallels can be drawn with research on schools in low socio- economic areas and the importance of developing the quality of the environment and the school:"... the success of efforts to make urban areas attractive to families with children is inextricably linked to the improvement of urban public education (Jude 2006, p . 74)." Education levels and creative occupations are internationally strongly related to regional development and income. What is of highly important influencing factors are creativity, technology and tolerance (Florida, Mellander \& Stolerick, 2010; Tomaney, \& Wray, 2011).

\subsection{Pedagogical Platform and Schools}

At a rapping on the concept of pedagogical platform at Google about 2860000 hits (2015-01-15) are given. Synonymous (but not replaceable) with the above concept is educational profile (195000 000 hits). Pedagogical platform is described as the starting points for the business from the holistic perspective. A review of schools' pedagogical platform shows great differences in the descriptions, ranging from several pages of concrete descriptions to a few lines with a more horizontal text. In terms of content example like values, view of knowledge teaching and learning, performance management, didactic approaches, learning environments and working approaches are described. In international research occurs both concepts educational and pedagogical platform. The concept of pedagogical platform is already described 1957 by Reavis (referenced by Barone, 1987) and which refers schools' fundamental and lasting educational philosophy.

This includes:

...topics aimed at and is responsible for training, school organization , program and curriculum , adaptation of teaching and learning, into account individual differences ; relationship between management, leadership, and the teacher values and issues in social sciences and research (Barone, 1987, p 32).

A pedagogical platform can be described as a holistic idea (cf. Scherp, 2011), which is a kind of main patterns of lessons created in organizational development and describes the connection between teachers work and achievement for the school. There is a link between the mission and everyday events and is the basis for learning processes. How the school's concrete work is performed in relation to the school's educational platform seem to have repercussion on organizational development, effectiveness , individualization , systematic process development and student performance (Dale , 1998; Nordahl et al . 2005) .

Regarding the three project schools pedagogical platform is not explicit described in their presentations. However, there are texts about the schools approaches, profile and core values for the mainstream school. For the Junior school ${ }^{1}$ there is no description at all on the website. The same applies for the Secondary school. Regarding the three reference schools there is a short text about the Primary school, which is comparable to the project school. The reference schools Secondary 1 and Secondary 2 have several sides of descriptions. One writes up real learning, innovation and entrepreneurship, but clear concretization, the other about versatility, international exchange and special sports.

\section{Method}

\subsection{Purpose and Research Questions}

The knowledge gap regarding schools' conscious development capacity in Västernorrland and Jämtland is important to fill in order to influence regional development and quality in teaching and learning. This may in turn have repercussions on teachers ' teaching and students' meta cognitive development. The purpose of this study is to compare the staff's perceptions of the educational platform on the project schools with reference schools to catch sight of internal development capabilities. The data used is the response from a web survey. The study intends to answer the following research questions:

Q1. Are there significant differences between the project schools and the reference schools regarding teachers' perceptions of pedagogical platform?

Q2. If significant differences exist, how are these described?

\subsection{Selection, Implementation and the Reference Schools}

The empirical material is collected during the second year of the project. Three schools in the two counties were selected for participation and here they have been provided with fictitious names; Junior school (F-5), Primary (F- 9) and Secondary school. One school located in what is known as the tourism and hospitality industry municipality and two schools in larger municipalities. However, one of the two schools in the larger municipality is located in the countryside, about one mile from the main town. The three reference schools are located in larger municipalities, but two of them a few miles outside the main town. The study is thus empirically based from project schools comparable with reference schools. The reference school and the primary school has many similarities, both geographically, socio -economically and in size.

\footnotetext{
${ }^{1}$ Project School will be named Junior (F-5), Primary (F-9) and Secondary school
} 
Both are situated one mile outside the city center, in a small society with close proximity to industries. In order to compare the two primary schools status the statistical analysis tool SALSA (www.skolverket.se 2014a) was used. It presents schools' results of final grades in 9th grade after some consideration has been given to the students. SALSA is a statistical model that compares municipalities and schools grade results. This means that municipalities and school performance are determined by the actual rating results are related to a number of background factors. Table 1 shows the important parameters such as the number of boys, parents' educational level and proportion of new immigrants, as well as merit ratings (both actual and modeled) and achieved goals in all subjects.

Table 1. SALSA results regarding the final score for the project school and the reference schools..

\begin{tabular}{lllllll}
\hline & Boys & $\begin{array}{l}\text { Parents } \\
\text { Educational } \\
\text { level }\end{array}$ & $\begin{array}{l}\text { Percentage } \\
\text { immigrants }\end{array}$ & $\begin{array}{l}\text { Conditioned } \\
\text { actually } \\
\text { average } \\
\text { merit }\end{array}$ & $\begin{array}{l}\text { Model } \\
\text { calculated } \\
\text { average } \\
\text { merit }\end{array}$ & $\begin{array}{l}\text { Achieved } \\
\text { goals in } \\
\text { all } \\
\text { subjects }\end{array}$ \\
\hline $\begin{array}{l}\text { Project } \\
\text { school }\end{array}$ & 0,55 & 2,13 & 0,02 & 206,79 & 208,9 & 0,77 \\
$\begin{array}{l}\text { Reference } \\
\text { school }\end{array}$ & 0,51 & 2,28 & 0,01 & 215,6 & 219,8 & 0,81 \\
\hline
\end{tabular}

As table1 shows, the schools are fairly comparable in terms of proportion of boys and new immigrants, but the reference school is just slightly higher as regards parental education. Reference school students perform better in terms of merit and achieved goals in all subjects.

In order to provide a basis for the secondary school in the project two reference schools were selected; one that performs about as well as school projects and one that is a bit lower in the results. Reference schools are located in the outskirts of large cities, but the structure is similar to the project's secondary school with limited range of programs, and the size of the number of pupils and staff. As a basis statistics SIRIS (Skolverket 2014b) were use showing students with completed grades.

Table 2. Results of final grades for the project school and the reference schools

\begin{tabular}{llllll}
\hline & Proposion \% graduated & $\begin{array}{l}\text { Proposion } \\
\% \text { with } \\
\text { graduated } \\
\text { submission } \\
\text { distinction }\end{array}$ & $\begin{array}{l}\text { GBP for students with exams } \\
\text { and study evidence }\end{array}$ & $\begin{array}{l}\text { GBP for students } \\
\text { with } \\
\text { exam }\end{array}$ & $\begin{array}{l}\text { Secondary } \\
\text { School }\end{array}$ \\
Work \\
Project school & 93,3 & 66,7 & 14,6 & 14,7 & 100 \\
Ref. school 1 & 85,9 & 60,9 & 13,3 & 13,8 & 99,2 \\
Ref. school 2 & 93,5 & 75,9 & 13,8 & 14,1 & 98,1 \\
\hline
\end{tabular}

1 GBP $=$ Average grade points

As shown in Table 2 the reference school is slightly higher than the two reference schools in basic eligibility for students with exams and study evidence and fully followed secondary school works and halfway between the two reference schools existing proposion \% with general admission.

\subsection{Methodology and Data Collecting Instruments}

The study is a cross-sectional survey with a descriptive exploratory purpose. Data were collected using a web-based questionnaire that was administered as a link questionnaire survey tool Netigate (www.netigate.se) for all teachers in the project and reference schools in spring 2014, with a reminder. Usable responses were received from 104 people in the project schools ( $85 \%$ of those contacted), and 56 people from the reference schools $(63 \%)$. With the survey followed a message that informed the study's purpose and that participation was voluntary and anonymous. The questionnaire consisted of ten questions about the pedagogical platform. First, questions were answered about background variables such as gender, age, number of teaching years, school size and educational level. Then themes were followed concerning the pedagogical platform with estimation issues. The survey questions covering first one overarching question about the staff's perception of the educational platform. Then aspects that can be part of a pedagogical platform were asked; proven experience and scientific basis, didactic choices and didactic skills, classroom management, target and performance, working teams, view of knowledge and the physical learning environment. Issues about regional development were also found in the survey. For each question there was an opportunity to comment on the answers. To one question only open-ended responses, could be given, namely the team organization and function. This study uses mainly the estimation issues, but at specific results open answers will be commented. Before the questionnaire was sent out it had been tested by ten teachers and peer reviewed in an academic forum. 
The query constructs for web survey consisted of a systematic operationalization of the theoretical concepts which the study is based on results of previous research and aspects of school improvement and regional development, which we consider relevant.

For qualitative data directed content analysis of the open answers were utilized where, which could show differences (Hsieh \& Shannon, 2005). The process is marked out of a certain structure where the initial coding is made based on past performance. This approach allows discussions from different theoretical perspectives. The goal of a qualitative directed content analysis is to validate or conceptually extend a theoretical framework or theory. The process followed the usual practice (cf. Graneheim \& Lundman, 2004): full text (analysis) is read through several times to get an overview. Through sentences or phrases the content was condensed to categories that reflect the core message. These categories represent the manifest content of the texts to finally find the theme / themes, where the latent content was evident. At the quotes used encoding R (= reference school) and V (project school) followed by a number to indicate the quotation order in the empirical data.

In order to achieve reliability in this part of the study following actions were taken; Credibility were matched purpose of the study and research questions, reliability (dependability) were handled by changes in researchers' decisions by analysis process consciously disregarded and transferability were analyzed on the basis of the extent to which the results can be transferred to other similar contexts and groups (Graneheim \& Lundman, 2004).

The study followed the Swedish Research Council's rules and ethical recommendations of the study in co-pour Scientific Research (www.vetenskapsrådet.se).

\subsection{Variables and Sample}

The intervention variable; Project schools; reference schools

Some background variables we considered to be potential confounders of the relationship between interventions variable and outcome factors. These potential confounders are listed below.

Education Level: Mainstream school, grades 1-9; secondary school

Gender: Female; one

Experience: 0-10 years of employment at school; more than 10 years of employment at school

Size of school: Up to 500 pupils; more than 500 students

\section{Factors}

Nine factors, based on different aspects of the schools' pedagogical platform, were measured with different number of items for each factor. Responses to items were measured on a scale of integers 1 to 5 ; in some cases were also given the opportunity for "Do not know" responses. Each factor score was calculated as the average of its items reply. The factors termed pedagogical platform, Scientific basis, Education, Leadership; Goals \& results; View of Knowledge; Learning environment and Regional development. In each of these includes ten to at least two items. Each factor were operationalized when the items were constructed in the development of the questionnaire, rather than through data analysis. Exception is the removal of an item regarding Scientific basis, two of the Goals \& results, and one from the View of knowledge. This was done to improve the factors of so-called internal consistency.

\section{Analysis}

A descriptive analysis of background variables were made as well as the responses to the questions on new scientific evidence. Factor internal consistency were measured by Cronbach's alpha, $\alpha$, after the pattern of the current "Missing" were analyzed for each factor separately. Minor edits were made as mentioned. A generally accepted rule of thumb that we used for assessing the internal consistency of a measurement scale is that the value of $\alpha$ is considered acceptable if $\alpha>0.7$, well if $\alpha>0.8$, and excellent if $\alpha>0.9$ (George and Mallery, 1999; Lockyer , 2003). Since the factors created as sums of variable values, we treat them as the interval scale variables.

Pedagogical platform; The extent to which employees perceive that there exist and are used an pedagogical platform exists in the school.

9 items; Cronbach's alpha $=0.953 ; \mathrm{n}=150 ;$ Missing: 10

Scientific basis; The extent to which employees perceive that the school is based on proven experience and scientific basis in school.

9 items ; Cronbach's alpha $=0.860 ; \mathrm{n}=144$; Missing : 16

Didactics; The extent to which employees perceive that the school is based on didactic choices and develop the didactic skills. 
9 items; Cronbach's alpha $=0.774 ; \mathrm{n}=139$; Missing: 21

Leadership; The extent to which employees perceive that they consciously develop and utilize leadership in the classroom.

9 items ; Cronbach's alpha $=0.839 ; \mathrm{n}=137$; Missing : 23

Goals and results; The extent to which employees perceive that they are actively working with performance management.

5 items ; Cronbach's alpha $=0.854 ; \mathrm{n}=123$; Missing : 37

View of knowledge; The extent to which employees perceive that they are actively working with the view of knowledge in school.

3 items ; Cronbach's alpha $=0.785 ; \mathrm{n}=123$; Missing : 37

Learning environment; The extent to which employees perceive that they actively work with the learning environment at school.

2 items ; Cronbach's alpha $=0.892 ; \mathrm{n}=118$; Missing : 42

Regional development; The extent to which employees perceive that schools are actively working with the region in school matters.

3 items; Cronbach's alpha $=0.740 ; \mathrm{n}=121$; Missing: 39

Regarding the answers about the way the respondents were informed about new scientific findings, respondents were allowed to select more than one answer, and the answers were analyzed with this in mind. The differences in the proportion who selected an answer between the project schools and Reference School, were calculated p-values with Fisher's exact test. In order to control for the effect of potential confounders, a multiple linear regression analysis was used. In this way each factor compared mean value between the project schools and reference schools under the control of background variables were assessed as potential confounders.

\section{Results}

\subsection{Quantitative Data}

To get an idea of the samples which this study relies on, is described in Table 3 with respect to the variables type of school, gender, age, experience of working in school and student numbers .

Table 3. Sample distribution over background variables

\begin{tabular}{lrr}
\hline Variable & $\begin{array}{r}\text { Project } \\
\text { school }\end{array}$ & $\begin{array}{r}\text { Reference } \\
\text { school }\end{array}$ \\
\hline School type & $\mathrm{n}=95$ & $\mathrm{n}=55$ \\
Elementary & $83 \%$ & $15 \%$ \\
Secondary & $17 \%$ & $85 \%$ \\
Gender & $\mathrm{n}=104$ & $\mathrm{n}=56$ \\
Female & $74 \%$ & $57 \%$ \\
Male & $26 \%$ & $43 \%$ \\
Age & $\mathrm{n}=102$ & $\mathrm{n}=56$ \\
$20-30$ years & $6 \%$ & $9 \%$ \\
$31-40$ years & $23 \%$ & $45 \%$ \\
$41-50$ years & $43 \%$ & $27 \%$ \\
$51-60$ years & $20 \%$ & $18 \%$ \\
61 years - & $9 \%$ & $2 \%$ \\
Experience of & $\mathrm{n}=101$ & $\mathrm{n}=56$ \\
school & & \\
$0-10$ years & $30 \%$ & $48 \%$ \\
More than 10 years & $70 \%$ & $52 \%$ \\
Student numbers & $\mathrm{n}=103$ & $89 \%$ \\
Small School & $44 \%$ & $11 \%$ \\
Larger school & $56 \%$ &
\end{tabular}

Some of background variables had completely different distribution in category Project school compared to the Reference school. In the Project schools $83 \%$ of the respondents worked at the primary level and $17 \%$ in secondary school, while in Reference School was almost exactly the opposite. In Project schools, $56 \%$ of respondents worked in a larger school, while in Reference School only $11 \%$ who did. Other background variables did not show such large differences between intervention variables categories when it comes to the distribution of responses. The nature of the differences in the distributions mentioned here plays a crucial role in the emergence of confounding in the effect of an intervention in this 
study, so it can be seen as a complication in the study. Another complication is that, especially among the reference schools were relatively few respondents in the categories Primary school and Larger School, which complicates the analysis.

The answers to the research question whether there are significant differences in teachers' perceptions about some parts in the pedagogical platform are reported in Tables 4 and 5. The overall mean value for each of the eight factors are recognized as the difference in mean value between the Project and Reference School under control education level, teachers' teaching experience and school size (Table 4). Furthermore, p-values for the differences were reported.

Table 4. Mean values and mean differences of factors, under control of confounders

\begin{tabular}{lccc}
\hline Factor & $\begin{array}{c}\text { Mean } \\
\text { estimated } \\
\text { factor }\end{array}$ & $\begin{array}{c}\text { Mean } \\
\text { difference }\end{array}$ & p-value \\
\hline Pedagogical platform & 3,21 & $-0,44$ & 0,036 \\
Scientific ground & 3,05 & 0,21 & 0,215 \\
Didactic & 3,66 & $-0,09$ & 0,501 \\
Leadership & 3,93 & $-0,25$ & 0,052 \\
Goal \& results & 3,47 & 0,22 & 0,309 \\
View of knowledge & 3,37 & 0,03 & 0,907 \\
Learning environment & 2,64 & $-0,02$ & 0,951 \\
Regional development & 3,19 & 0,22 & 0,191 \\
\hline
\end{tabular}

${ }^{1}$ A negative value indicates that the Project schools averages were lower than the Reference schools, positive that they were higher.

We can see that the mean factor pedagogical platform was 0.44 lower for Project schools compared with reference schools $(\mathrm{p}=0.036)$. The difference was statistically significant. Leadership - factors of importance for the Project schools was 0.25 lower compared to reference school, which was an almost statistically significant difference $(p=0.052)$.

For factors Scientific basis, Goals \& results and Regional development the project schools mean value was 0.21 to 0.22 higher than the reference schools (p-values from 0.191 to 0.309 ). These differences were not statistically significant. The differences for the factors Didactic, View of knowledge and the Learning environment was very small and far from significant. (P values in the range 0.50 to 0.95 ). In conclusion, we note that the factors Didactic and Leadership had high values both for the Project and Reference schools. The factor Leadership had slightly lower value for Reference schools and somewhat higher in Reference schools. The factor Pedagogical platform had a statistically significant difference to the reference schools benefit. Learning environment factor had remarkably low value in both school categories. As far as which way the staff took part in new scientific evidence, respondents could select more than one answer. Table 5 describes how the staff in the school categories considers themselves to take advantage of new scientific knowledge.

Table 5. Takes part of new scientific knowledge through various ways, and number of shares

\begin{tabular}{lccccc}
\hline New scientific knowledge & $\begin{array}{l}\text { Reference school } \\
\text { Percen-tage }^{1}\end{array}$ & Number & $\begin{array}{l}\text { Project school } \\
\text { Percen-tage }^{1}\end{array}$ & Number & p-value, (Exact test) \\
\hline Takes part through commissioned & $8,5 \%$ & 4 & $41,9 \%$ & 39 & 0,000 \\
programs & $42,6 \%$ & 20 & $53,8 \%$ & 50 & 0,283 \\
Take part via the Web & $29,8 \%$ & 14 & $65,6 \%$ & 61 & 0,000 \\
Takes part through conferences & $42,6 \%$ & 20 & $49,5 \%$ & 46 & 0,477 \\
Takes part through the team meeting & $72,3 \%$ & 34 & $80,6 \%$ & 75 & 0,286 \\
Take part through their own studies & $8,5 \%$ & 4 & $11,8 \%$ & 11 & 0,773 \\
Will not take part in scientific knowledge & & & & & \\
\hline
\end{tabular}

${ }^{1}$ Percentages based on respondents

The proportion of staff who respond that they partake of new scientific knowledge through commissioned programs and the percentage who make it through conferences are $8.5 \%$ and $29.8 \%$ for the reference schools while the corresponding proportions for project school category is $41.9 \%$ and $65.6 \%$. P- values for these differences is 0.000 . The proportion of respondents that they were not partake of such things is low in both categories; $8.5 \%$ and $11.8 \%$ (p value 0.773 ). Finally, when it comes to some of these news via the web, through team meetings or private study is 8-11 percentage points higher proportion among project school staff than reference school staff who answer this ( $\mathrm{p}$-values 0.283 to 0.477 ).

In summary, there are differences in what manner and also the extent to which teachers take part in scientific news from project and reference schools. All sources to take advantage of these new features are utilized by a larger proportion of teachers in project schools, however, are the differences in the proportion who take part via the web, team meetings and individual studies are not significant counted separately. What distinguishes the most is the percentage who partakes of the new science through mission training as well as through conferences.

\subsection{Qualitative Data}


When two of the factors, Pedagogical platform and Leadership, showed significant differences in the responses, the open answers have been examined through a directed content analysis. To gain a deeper understanding the completely open ended question concerning teams have been analyzed. The directed content analysis takes into on the distinctive aspects and thematized them. Regarding awareness of the pedagogical platform there is a quantitative difference; more comments are given by Project schools. In terms of content revealed two distinctive themes:

Understanding vs ambiguity

The responses from the reference schools can be described as more understanding of the school's overall pedagogical platform where there seems to be common pedagogical strategies and tools. A description is the following:

Very controlled work with several tools that work together. Tightly controlled templates for how the LPP (local pedagogical planning) should be written with intermediate targets for pupils, reading strategies, etc. (R 22).

The responses from the Project schools show generally the lack of clarity regarding the pedagogical platform. Half of all responses wonder if it exist, what it does and sometimes it does not exist at all. Half of the responses has defined the school's platform as we're preparing for life, personalization, internationalization.

Specifically targeting vs. general descriptions

Reference schools describes clearly the school's focus, for example, entrepreneurial work summative and formative assessment, while the Project schools descriptions are more general. The following comment may exemplify this: "We have a profile, but I do not think it says something about how we work pedagogical, therefore I do not count it as a profile (v54).”

Regarding awareness of classroom management there are so few open-ended responses, so the question cannot be analyzed. To gain a greater understanding of result of the web survey, the open ended question about team were also analyzed through directed content analysis. First, there is a quantitative difference: many more comments from the Project schools. Secondly, there are three distinctive substantive themes:

The composition team working

Project schools exhibit a heterogeneous picture of the team work organization, ranging from no team at all to only one for the whole school to old age or substance designed teams. Reference schools are generally clearer in the organization which developed written as subject- programs - or stage teams, and in some cases related to working team councils.

The teams' organization in relation to the pedagogical profile

Also in this respect the Project schools response much more diverse and negative descriptions compare to the reference schools. Approximately two- thirds of the Project schools responses say that it is not organized teams according to the pedagogical platform. Only a few people in the reference schools have indicated that this is the case.

The team supporting the pedagogical work

The responses from the reference schools clearly indicate that the team supports the pedagogical work. The following quote may illustrate this: "We discuss, for example, assessment and pedagogical and didactic improvements in various subjects ( $R$ 210). "The responses from the Project schools are much higher degree of doubt if this is the case.

In conclusion, it was found qualitative differences between teachers in the project schools and reference schools regarding the pedagogical platform clarity and concretization and the work team organization, design and pedagogical underpinning.

\section{Discussion}

\subsection{Summary of Conclusions}

This article compares teachers' perceptions in three projects schools in a school development project concerning the pedagogical platform compared to teachers in reference schools. The background to the project is declining school performance and competence escape of university graduates from the two counties of Västernorrland and Jämtland, Based on research and partly on Regional Development (Florida et al . 2010) and partly School Improvement Theory (Höög \& Johansson 2011; 2014), the study designed to identify potential increase capacity in the Project schools.

Studies aim has been to catch sight of "invisible mechanisms" (cf. Franzen, 2011) or the collective perceptions of the pedagogical platform in schools. To achieve this, a web questionnaire with ten questions covering various aspects of the pedagogical platform was sent teachers at three schools projects and three reference schools. The questionnaire consisted of mostly estimation questions with direct answers for comments. The research questions was to find out whether there are significant differences in perceptions between the two school types and how these differences in such cases are described. 
Three areas in which significant differences were estimates; the pedagogical platform, leadership, and how new scientific findings were provided. The project schools have significantly lower values in terms of perceptions of the pedagogical platform and leadership compared with the reference schools. However, the project schools have higher estimated values concerning competence development through commissioned programs and conferences. This could possibly be explained by the ongoing project. The directed content analysis shows that the project schools expresses that the pedagogical platform is vague and more general compared to the reference schools, which writes up more understanding and concreteness in their responses. This may in part relate to the project schools platform, which is projected to a lesser extent on the websites compared to the reference schools. Further, the content analysis shows that team work is clearer and more homogeneous at the reference schools compared to the project schools. This can also be an explanation for the statistical results, ie that teachers at the Project schools are not to the same extent aware of the pedagogical foundation as the teachers at the reference schools.

The answer to the question- is there a connection between school improvement and regional development - this study cannot comment on that. In contrast, it seems that teachers in rural schools (or in schools with low merit ratings (cf Jud, 2006) should be even more aware of the educational platform and work accordingly. If the staff in project schools focused on and pedagogical platform and leadership this would raise student' achievement

On the other hand, there is something teachers do in project schools which impact on student performance that is not seen in this study. When the project schools have basically the same grade level as the reference schools but have less awareness of the educational platform, there are other important factors in these schools that contribute to student achievement. What remains to be explored?

\subsection{Pedagogical Implications}

If schools to successfully support students' learning research is pointing at three major aspects; structure, culture and leadership (eg Höög \& Johansson, 2011; 2014). In this study important aspects of culture and leadership for improvement could be suggested in project schools. One area for improvement for the project schools is to capture the common pedagogical platform (cf. Scherp, 2011). When the collective have a common picture their professional identities possibly can be coincide. When teachers' professional identities coincide with the school's ability to achieve both learning and social objectives (Olofsson, 2014) affected student performance. If awareness of their own platform (profile) permeates all staff, this may affect team work (cf. Bjorkman 2008; Blossing, 2008). Thereafter, the leadership aspects are focused, ie paths to teacher leadership (Steinberg, 2012). About insights into regional development should be able to permeate the whole pedagogical system especially in rural / rural municipalities and other exposed areas schools' educational approaches should be clarified.

\subsection{Continued Research}

An area of development in this context is to review the standards prevailing in school cultures (Dimenäs et al. 2013; Rönnblom, 2014). What values permeate all teaching; urban, rural or others? Another area is to follow up the project schools' development. Then the teachers clearly felt that training efforts on scientific grounds was conducted through conferences and training might knowledge and values change over time.

\section{Acknowledgements}

The authors would like to thank Activities of business and employers membership organizations in Mid Sweden County Administrative Board in Västernorrland, and Activities of business and employers membership organisations in the County of Jämtland for their support.

\section{References}

Ambos, B., \& Schlegelmilch, B. (2010). The new role of regional management. Vienna: Palgrave Macmillan.

Berg, G., \& Scherp, H. Å. (2009). Skolutvecklingens många ansikten. Forskning i fokus, nr 15. Stockholm: Myndigheten för skolutveckling.

Barone, T. (1987). Educational Platforms, Teacher Selection, and School Reform: Issues Emanating from a Biographical Case Study. Journal of Teacher Education, 38, 12-17. http://dx.doi.org/10.1177/002248718703800204

Björkman, C. (2008). Internal capacities for school improvement: principals' views in Swedish secondary schools (diss). Umeå; Umeå University.

Blossing, U. (2008). Kompetens för samspelande skolor. Om skolorganisationer och skolförbättring. Lund: Studentlitteratur. 
Boström, L. (2015a). Regional Educational Development Research in Sweden of Forty Years. Journal of Studies in Education, 5(2), 1-21. http://dx.doi.org/10.5296/jse.v5i2.7197

Boström, L. (2015b). Regional Educational Development Research and School Improvement: Teaching and Educational Research, 11(1), 200-211.

Bredeson, P. (2002). The Architecture of Professional Development: Materials, Messages and Meaning. International Journal of Educational Research, 37(8), 661-675 http://dx.doi.org/10.1016/S0883-0355(03)00064-8

Chance, P., \& Segura, S. (2009). A Rural High School's Collaborative Approach to School Improvement. Journal of Research in Rural Education, 24(5).

Dale, E. L. (1998). Utdanning med pedagogisk profesjonalitet. Oslo: Forlaget Klim.

Dimenäs, J., Kolbeck, K., Wede, C., \& Norlund, A. (2013). "En trygg och framgångsrik skola"- pedagogiska övertygelser i fyra landsortsskolor. Utbildning \& Demokrati, 2, 81-104.

Ertesvåg, S. K. (2009). Classroom leadership: The effect of a school development programme. Educational Psychology, 29(5), 515-539. http://dx.doi.org/10.1080/01443410903122194

Florida, R., Mellander, C. \& Stolarick, K. (2010). Talent, technology and tolerance in Canadian regional development. The Canadian Geographer, 54(3), 277-304. http://dx.doi.org/10.1111/j.1541-0064.2009.00293.x

Franzén, K. (2011). Att synliggöra det osynliga - hur går det till? In U. Blossing, Skolledaren i fokus - kunskap, värden och verktyg. Lund: Studentlitteratur

From, J., \& Olofsson, A. (2014). Kunskapsekonomi och regional utveckling. [Knowledge Economy and Regional Development]. In Y. Fiedrichs, M. Gawell \& J. Wincent (Eds.), Samhällsentreprenörskap för lokal utveckling (pp. 17-42). Sundsvall: Mittuniversitetet.

Fullan, M. (2010). Leadership Development: The larger Context. Instructional Leadership, 45-49.

George, D., \& Mallery, P. (1999). SPSS for Windows Step by Step: a Simple Guide and Reference. Boston: Allyn and Bacon.

Graneheim, U. H., \& Lundman, B. (2004). Qualitative content analysis in nursing research: concepts, procedures and measures to achieve trustworthiness. Nurse Education Today, 24(2), 105-112 http://dx.doi.org/10.1016/j.nedt.2003.10.001

Hernandez, F., \& Goodsson, I. F. (2010). Social geographies of educational changes: Drawing a map for curious and dissatisfied travellers. Social and Geographies of Educational Changes (ss. xi-xxi). Dordrecht: Kluwer Academic Publisher.

Hsieh, H., \& Shannon, S. (2005). Three approaches to qualitative content analysis. Qualitative health research, 15(9), 1277-1288 http://dx.doi.org/10.1177/1049732305276687

Höög, J., \& Johansson, O. (2014). Framgångsrika skolor - mer om struktur, kultur, ledarskap. . Lund: Studentlitteratur

Höög, J., \& Johansson, O. (2011). Struktur, kultur och ledarskap - ett projekt och dess resultat. In J. Höög och O. Johansson, Struktur, kultur och ledarskap - förutsättningar för framgångsrika skolor. Lund: Studentlitteratur.

Jud, D. (2006). Public Schools and Urban Development. Journal of the American Planning Association, 51(1), 74-83, http://dx.doi.org/10.1080/01944368508976803

Kauppila, P. (2011). Cores and Peripheries in a northern periphery: a case study in Finland. Fennia, 189(1), 20-31.

Klaesson, J., \& Pettersson, L. (2009). Urban and Rural Development in Sweden, In Karlsson, C, Andersson, Å.E., Cheshire, P.C. and Stough, R.R. New Directions in Regional Economic Development, Berlin: Springer. http://dx.doi.org/10.1007/978-3-642-01017-0_17

Lockyer, J. (2003). Multisource Feedback in the Assessment of Physcian Competencies". The Journal of Continuing Education in the Health Professions, 5, 4-12. http://dx.doi.org/10.1002/chp.1340230103

Löfgren, H. (2012). Det sitter inte i väggarna. Yrkesidentiteter i lärares berättelser om skola och arbete. (diss). Karlstad; Karlstads University Studies, 1.

Mittuniversitetet (2012). Projektplan Världens bästa regionala utbildningssystem.

Nordahl, T., Sørlie, M. A., Manger, T., \& Tveit, A. (2005). Atferdsproblemer blant barn og unge. Teoretiske og praktiske tilnarminger. Bergen: Fagbokforlaget.

Olofsson, A. (2014). Olika skolor - olika läraridentiteter. In J. Höög och O. Johansson. Framgångsrika skolor - mer om 
struktur, kultur, ledarskap. Lund: Studentlitteratur

Pounder, J. S. (2008). Full-range Classroom Leadership: Implications for the Cross-organizational and Cross-cultural Applicability of the Transformational-transactional Paradigm. Leadership, 4(2), 115-135. http://dx.doi.org/10.1177/1742715008089634

Rönnblom, M. (2014). Ett urbant tolkningsföreträde? En studie av hur landsbygden skapas i nationell policy. Umeå: Umeå centrum för genusstudier, Umeå Universitet.

Scherp, H. Å. (2011). Varför gör vi det vi gör när det som händer händer? In U. Blossing, Skolledaren i fokus - kunskap, värden och verktyg. Lund: Studentlitteratur.

Skolverket. (2014a). SALSA/ SIRIS.http://www.skolverket.se/statistik-och-utvardering/statistik-i-databaser. 2014-02-02

Skolverket. (2014b). SALSA/ SIRIS. http://www.skolverket.se/statistik-och-utvardering/statistik-i-databaser

Statistiska, C. (2014). Utflyttande högskoleutbildade från Jämtlands och Västernorrlands län. [Out-migration of college-educated in Jämtlands and Västernorrlands counties compared to the whole of Sweden]. http://www.scb.se/sv_/Hitta-statistik/

Steinberg, J. (2012). Att leda klassrumshantverket. In G Berg, F Sundh och C Wede, Lärare som ledare -i och utanför klassrummet. Lund: Studentlitteratur.

Tomaney, J., \& Wray, F. (2011). The University and the Region: An Australian Perspective. International Journal of Urban and Regional Research , 35, 5 913-931. http://dx.doi.org/10.1111/j.1468-2427.2011.01020.x

Veugelers, W., \& Zijlstra, H. (2010). Networks of schools and constructing citizenship in secondary education. In F. Hernandez \& I. Goodson (Eds.), Social geographies of educational changes (pp. 65-78). Dordrecht: Kluwer Academic Publishers.

This work is licensed under a Creative Commons Attribution 3.0 License. 